\title{
A prospective study of mortality among middle-aged diabetic patients (the London cohort of the WHO Multinational Study of Vascular Disease in Diabetics) II: associated risk factors
}

\author{
N. J.Morrish ${ }^{1}$, L. K. Stevens ${ }^{3}$, J.Head $^{3}$, J.H.Fuller ${ }^{3}$, R. J. Jarrett ${ }^{2}$ and H.Keen ${ }^{1}$ \\ ${ }^{1}$ Unit for Metabolic Medicine, ${ }^{2}$ Department of Community Medicine, United Medical and Dental Schools (Guy's Campus), and \\ ${ }^{3}$ Department of Community Medicine, University College and Middlesex School of Medicine, London, UK
}

\begin{abstract}
Summary. Potential risk factors have been examined for association with mortality over a 10-12 year follow-up of the patients of the London Cohort of the WHO Multinational Study of Vascular Disease in Diabetics (aged 35-54 years at entry to the study). Proteinuria has the strongest association with all-cause mortality in univariate analysis being significant in patients of both sexes with Type 2 (non-insulin-dependent) diabetes mellitus and in women with Type 1 (insulin-dependent) diabetes mellitus; both systolic blood pressure (men) and hypertension (both sexes) (as a categorical variable) are significant in Type 1 diabetes. Hypertension is also significantly associated with all-cause mortality in multivariate analysis in both sexes with Type 1 diabetes as proteinuria is in women with Type 2 diabetes. There is an unexpected negative association between plasma creatinine and all-cause mortality in men with Type 2 diabetes. Systolic blood pressure and hypertension are also significantly linked with cardiovascular mortality in Type 1 diabetes, hypertension having an estimated relative risk of 18.6 in multivariate
\end{abstract}

analysis. Serum cholesterol and proteinuria showed the strongest associations with cardiovascular mortality in Type 2 diabetes. Proteinuria is associated with non-cardiovascular mortality in both types of diabetes in univariate but not multivariate analysis. In multivariate analysis hypertension (Type 1 diabetes) and diabetes duration (Type 2 diabetes) are associated with non-cardiovascular mortality. Hypertension and proteinuria have the most consistent associations with mortality in the different analyses with the effect of hypertension appearing stronger in Type 1 diabetes and proteinuria in Type 2 diabetes. Some other proven risk factors in non-diabetic populations had inconstant or absent associations in this group: other, as yet undefined, factors may be important in diabetes.

Key words: Mortality, Type 1 (insulin-dependent) diabetes, Type 2 (non-insulin-dependent) diabetes, risk factors, hypertension, proteinuria.
The reasons for the excess cardiovascular mortality in diabetes remain ill-defined at present; it is not clear to what extent this excess is attributable to an increased prevalence or force of established risk-factors for cardiovascular mortality in non-diabetic populations and to what extent specifically diabetes related-factors may play a role. This report examines deaths during a 10-12 followup of the 497 members of the London Cohort of the WHO Multinational Study of Vascular Disease in Diabetics (WHO Study) [1] and relates them to a variety of factors, some general and some diabetes related, ascertained at baseline.

\section{Subjects and methods}

The composition and recruitment of the London WHO Study cohort have been detailed elsewhere $[1,2]$. There were almost equal numbers of men and women aged $25-54$ years old at the initial examinations in 1975-1977. Recruitment was stratified by age and diabetes duration. A diabetic patient was defined as a person who had been diagnosed at least one year earlier and who was receiving treatment for diabetes at one of the study centres at entry to the study. Patients who started insulin treatment within one year of diagnosis and who remained on it are regarded as having Type 1 (insulin-dependent) diabetes. The measurements made at baseline have been described elsewhere [1]; in this report we consider blood pressure, blood 
Table 1. Baseline mean values ( $\pm \mathrm{SD}$ ) of continuously distributed variables

\begin{tabular}{|c|c|c|c|c|}
\hline & \multicolumn{2}{|c|}{$\begin{array}{l}\text { Patients with Type } 1 \\
\text { (insulin-dependent) } \\
\text { diabetes }(n=240)\end{array}$} & \multicolumn{2}{|c|}{$\begin{array}{l}\text { Patients with Type } 2 \\
\text { (non-insulin-dependent) } \\
\text { diabetes }(n=246)\end{array}$} \\
\hline & $\begin{array}{l}\text { Male } \\
n=11.8\end{array}$ & $\begin{array}{l}\text { Female } \\
n=136\end{array}$ & $\begin{array}{l}\text { Male } \\
n=125\end{array}$ & $\begin{array}{l}\text { Female } \\
n=118\end{array}$ \\
\hline Age (years) & $\begin{array}{l}44.9 \\
(6.0)\end{array}$ & $\begin{array}{l}47.7 \\
(5.6)\end{array}$ & $\begin{array}{l}45.8 \\
(5.6)\end{array}$ & $\begin{array}{l}47.9 \\
(5.3)\end{array}$ \\
\hline $\begin{array}{l}\text { Systolic BP } \\
(\mathrm{mm} \mathrm{Hg})\end{array}$ & $\begin{array}{l}134.8 \\
(20.7)\end{array}$ & $\begin{array}{l}134.0 \\
(22.4)\end{array}$ & $\begin{array}{l}134.2 \\
(21.5)\end{array}$ & $\begin{array}{l}143.2 \\
(26.7)\end{array}$ \\
\hline $\begin{array}{l}\text { Diastolic BP } \\
\text { (mm } \mathrm{mg})\end{array}$ & $\begin{array}{c}79.0 \\
(10.0)\end{array}$ & $\begin{array}{c}78.9 \\
(12.0)\end{array}$ & $\begin{array}{c}84.2 \\
(11.4)\end{array}$ & $\begin{array}{c}87.8 \\
(12.5)\end{array}$ \\
\hline $\begin{array}{l}\text { Serum cholesterol } \\
(\mathrm{mmol} / \mathrm{l})\end{array}$ & $\begin{array}{c}6.0 \\
(1.0)\end{array}$ & $\begin{array}{c}6.1 \\
(1.2)\end{array}$ & $\begin{array}{c}5.8 \\
(1.2)\end{array}$ & $\begin{array}{c}5.8 \\
(1.2)\end{array}$ \\
\hline $\begin{array}{l}\text { Plasma creatinine } \\
(\mu \mathrm{mol} / 1)\end{array}$ & $\begin{array}{c}86.6 \\
(13.3)\end{array}$ & $\begin{array}{c}74.2 \\
(14.1)\end{array}$ & $\begin{array}{c}89.3 \\
(15.9)\end{array}$ & $\begin{array}{c}73.4 \\
(15.0)\end{array}$ \\
\hline $\begin{array}{l}\text { Body mass index } \\
\mathrm{kg} / \mathrm{m}^{2}\end{array}$ & $\begin{array}{l}23.7 \\
(2.5)\end{array}$ & $\begin{array}{l}24.5 \\
(3.5)\end{array}$ & $\begin{array}{l}26.0 \\
(3.7)\end{array}$ & $\begin{array}{l}28.1 \\
(5.1)\end{array}$ \\
\hline $\begin{array}{l}\text { Diabetes duration } \\
\text { (Years) }\end{array}$ & $\begin{array}{l}20.2 \\
(9.8)\end{array}$ & $\begin{array}{c}20.0 \\
(11.3)\end{array}$ & $\begin{array}{c}7.0 \\
(5.5)\end{array}$ & $\begin{array}{c}7.9 \\
(6.2)\end{array}$ \\
\hline
\end{tabular}

$\mathrm{BP}=$ blood pressure

Table 2. Baseline values (\%) of categorical variables tested for relation with prospective mortality

\begin{tabular}{|c|c|c|c|c|}
\hline & \multicolumn{2}{|c|}{$\begin{array}{l}\text { Patients with Type } 1 \\
\text { (insulin-dependent) } \\
\text { diabetes }(n=240)\end{array}$} & \multicolumn{2}{|c|}{$\begin{array}{l}\text { Patients with Type } 2 \\
\text { (non-insulin-dependent) } \\
\text { diabetes }(n=246)\end{array}$} \\
\hline & Male & Female & Male & Female \\
\hline $\begin{array}{l}\text { Smoking: } \\
\text { Current } \\
\text { Ex-smoker } \\
\text { Never }\end{array}$ & $\begin{array}{l}47(40 \%) \\
39(33 \%) \\
32(27 \%)\end{array}$ & $\begin{array}{l}41(33 \%) \\
36(29 \%) \\
48(38 \%)\end{array}$ & $\begin{array}{l}57(42 \%) \\
44(32 \%) \\
35(26 \%)\end{array}$ & $\begin{array}{l}42(36 \%) \\
19(16 \%) \\
57(48 \%)\end{array}$ \\
\hline $\begin{array}{l}\text { Proteinuria: } \\
\text { Absent } \\
\text { Present }\end{array}$ & $\begin{array}{l}95(81 \%) \\
22(19 \%)\end{array}$ & $\begin{array}{r}100(80 \%) \\
25(20 \%)\end{array}$ & $\begin{array}{r}110(82 \%) \\
25(18 \%)\end{array}$ & $\begin{array}{l}93(79 \%) \\
25(21 \%)\end{array}$ \\
\hline $\begin{array}{l}E C G: \\
\text { Normal } \\
\text { Abnormal }\end{array}$ & $\begin{array}{l}99(84 \%) \\
19(16 \%)\end{array}$ & $\begin{array}{r}105(85 \%) \\
19(15 \%)\end{array}$ & $\begin{array}{r}111(82 \%) \\
24(18 \%)\end{array}$ & $\begin{array}{l}87(75 \%) \\
29(25 \%)\end{array}$ \\
\hline $\begin{array}{l}\text { Hypertension: } \\
\text { Absent } \\
\text { Present }\end{array}$ & $\begin{array}{l}94(80 \%) \\
24(20 \%)\end{array}$ & $\begin{array}{l}98(78 \%) \\
27(22 \%)\end{array}$ & $\begin{array}{r}104(77 \%) \\
32(23 \%)\end{array}$ & $\begin{array}{l}73(62 \%) \\
45(38 \%)\end{array}$ \\
\hline
\end{tabular}

Note: Proteinuria is defined as the presence of any degree of visible precipitation on the salicylsulphonic acid test. Hypertension includes patients with elevated blood pressure (systolic $B P \geqslant 160$ or diastolic $\mathrm{BP} \geqslant 95 \mathrm{~mm} \mathrm{Hg}$ ) and those on anti-hypertensive medication. ECGs were classified as follows; abnormal; major $Q$ waves or complete left bundle branch block (Minnesota codes 1-1, 1-2, 7-1), ST segment abnormalities if accompanied by abnormal $T$ waves, minor Q/QS wave changes (Minnesota codes 1-3, or any of 4-1, 4-2, 4-3 if accompanied by 5-1 or 5-2 or 5-3 and normal (all other Minnesota codes)

cholesterol and creatinine, body mass index, diabetes duration, proteinuria, ECG abnormality and smoking.

At the original visit a standardised structured enquiry was made about the duration, treatment and complications of the diabetes. Other biomedical details such as smoking habits and medication were recorded and the WHO cardiovascular questionnaire of Rose and Blackburn [3] was administered. Height and weight were recorded in indoor clothing but without shoes. Arterial blood pressure was measured in the right arm after sitting for $10 \mathrm{~min}$, using a standard mercury sphygmomanometer. A 12-lead resting ECG was recorded and was classified as to the likelihood of coronary heart disease using the Minnesota Code [3]. Blood was taken for the measurement of plasma creatinine and serum cholesterol in a central laboratory. Total urinary protein was estimated semiquantitatively by the salicylsulphonic acid method [4].

Baseline proteinuria is defined in this paper as the presence of any degree of visible precipitation in the salicylsulphonic acid test. The category of hypertension includes patients with elevated blood pressure (systolic blood pressure $\geqslant 160$ or diastolic blood pressure $\geqslant 95$ ) and those receiving antihypertensive medication. Baseline ECGs were grouped according to the results of Minnesota coding: 1) coronary heart disease probable; major $\mathrm{Q}$ waves or complete left bundle branch block (Minnesota codes 1-1, 1-2, 7-1) 2) coronary heart disease possible; ST segment abnormalities if accompanied by abnormal $\mathrm{T}$ waves, minor Q/QS wave changes (Minnesota codes 13 , or any of $4-1,4-2,4-3$ if accompanied by $5-1$ or $5-2$ or $5-3,3$ ) coronary heart disease unlikely (all other Minnesota codes). ECG results in this analysis are divided into abnormal; groups 1) and 2) above and normal; group 3). Cardiovascular deaths are those with an underlying cause (judged by the WHO Study mortality committee) with ICD Codes 390-459 and 798.1 [5] (International Classification of Diseases, 9 th revision, 1977 ).

Permission for the study was obtained from the Ethics Committees of the participating hospitals and informed consent from the patients entering the study.

\section{Statistical analysis}

Statistical analysis was performed using the Cox proportional hazard regression model [6]. Where relevant the analyses are adjusted for age and/or sex. For the continuously variable risk factors (e.g. blood pressure) the results of the Cox regression analyses are given as standardised estimates of relative risk. These were calculated by exp [regression coefficient for the variable $\times$ standard deviation of the variable]. This estimates the relative risk associated with a change of one standard deviation for that particular variable. $95 \%$ confidence intervals were calculated by exp [(coefficient $\times$ SD of variable $) \pm(1.96 \times$ (SEM of coefficient $\times$ SD of variable $))]$. For the categorical variables (e.g. proteinuria vs no proteinuria) the estimates of relative risk (exp [regression coefficient]) relate to the relative risk of one category compared with the other. Variables were entered into the multivariate regression model using the maximum partial likelihood ratio method. In the multivariate analyses the categorical variable hypertension was entered to represent arterial blood pressure with systolic and diastolic blood pressures omitted.

\section{Results}

There were 92 deaths among the 497 members of the cohort during the follow-up period to 31 July 1987 details of which are reported elsewhere [2]. Descriptive statistics for baseline variables which have been analysed for association with mortality are shown by sex and type of diabetes in Table 1 (continuously distributed variables) and Table 2 (discrete variables).

\section{Risk factors for all-cause mortality}

The relationship between selected baseline variables and all-cause mortality has been analysed separately for men and women with Type 1 diabetes and Type 2 diabetes. The results of univariate Cox regression analysis after adjust- 
Table 3. Univariate Cox regression analysis of association between risk factors and all cause mortality in patients with Type 1 (insulindependent) diabetes (adjusted for age)

\begin{tabular}{|c|c|c|}
\hline & Males $(n=117)$ & Females $(n=123)$ \\
\hline & $\begin{array}{l}\text { Standardised estimate } \\
\text { of relative risk }(95 \% \mathrm{CI})\end{array}$ & $\begin{array}{l}\text { Standardised estimate } \\
\text { of relative risk }(95 \% \mathrm{CI})\end{array}$ \\
\hline \multicolumn{3}{|c|}{ a) Continuous variables } \\
\hline $\begin{array}{l}\text { Systolic } \\
\text { BP }\end{array}$ & $1.5^{\mathrm{a}}(1.01-2.3)$ & $1.4(0.99-2.1)$ \\
\hline $\begin{array}{l}\text { Diastolic } \\
\text { BP }\end{array}$ & $1.4(0.9-2.3)$ & $1.0(0.7-1.6)$ \\
\hline $\begin{array}{l}\text { Serum } \\
\text { cholesterol }\end{array}$ & $1.0(0.6-1.6)$ & $0.9(0.6-1.4)$ \\
\hline $\begin{array}{l}\text { Plasma } \\
\text { creatinine }\end{array}$ & $1.5(0.9-2.4)$ & $1.2(0.7-1.6)$ \\
\hline $\begin{array}{l}\text { Body mass } \\
\text { index }\end{array}$ & $0.9(0.6-1.4)$ & $0.9(0.6-1.3)$ \\
\hline \multirow{2}{*}{$\begin{array}{l}\text { Diabetes } \\
\text { duration }\end{array}$} & $1.3(0.8-2.0)$ & $1.1(0.7-1.6)$ \\
\hline & $\begin{array}{l}\text { Estimate of relative risk } \\
(95 \% \mathrm{CI})\end{array}$ & $\begin{array}{l}\text { Estimate of relative risk } \\
(95 \% \mathrm{CI})\end{array}$ \\
\hline \multicolumn{3}{|c|}{ b) Categorical variables } \\
\hline $\begin{array}{l}\text { Proteinuria } \\
\text { (yes/no) }\end{array}$ & $2.1(0.8-5.6)$ & $2.9^{\mathrm{b}}(1.2-6.7)$ \\
\hline $\begin{array}{l}\text { ECG } \\
\text { (abnormal/ } \\
\text { normal) }\end{array}$ & $0.5(0.1-2.2)$ & $3.2^{\mathrm{b}}(1.3-7.5)$ \\
\hline $\begin{array}{l}\text { Hypertension } \\
\text { (present/ } \\
\text { absent) }\end{array}$ & $3.1^{\mathrm{a}}(1.2-8.3)$ & $3.9^{\mathrm{b}}(1.8-8.8)$ \\
\hline $\begin{array}{l}\text { Smoking } \\
\text { (current) } \\
\text { never) }\end{array}$ & $1.0(0.6-1.9)$ & $1.1(0.7-1.9)$ \\
\hline
\end{tabular}

ing for age are shown in Table 3 for patients with Type 1 diabetes and in Table 4 for patients with Type 2 diabetes.

Systolic blood pressure is positively related to allcause mortality in patients with Type 1 diabetes of both sexes. Amongst men with Type 1 diabetes the standardised estimate of relative risk (SERR) is $1.5(p<0.05)$ and among women with Type 1 diabetes 1.4 (ns, $p<0.2)$. The association is much less clear among patients with Type 2 diabetes (men SERR $=1.2$, women $\mathrm{SERR}=1.0$ ). In men with Type 1 diabetes the SERR for diastolic blood pressure is 1.4 (ns, $p<0.2$ ) and in women with Type 1 diabetes it is 1.0. Hypertension at baseline was significantly associated with mortality in both men and women with Type 1 diabetes with relative risks of 3.1 $(p<0.05)$ and $3.9(p<0.01)$ respectively, in patients with Type 2 diabetes hypertension carried a relative risk of 2.0 in men (ns, $p<0.1$ ) and 1.5 in women (ns, $p<0.3$ ). Proteinuria is positively associated with all-cause mortality in both sexes and both types of diabetes and statistically significantly in all but the men with Type 1 diabetes where the estimate of relative risk was 2.1. An abnormal ECG at baseline is strongly associated with all-cause mortality in women with Type 1 diabetes $(E R R=3.2$, $p<0.01)$. Baseline plasma creatinine was found unexpec-
Table 4. Univariate Cox regression analysis of association between risk factors and all cause mortality in patients with Type 2 (noninsulin-dependent) diabetes (adjusted for age)

\begin{tabular}{|c|c|c|}
\hline & Males $(n=132)$ & Females $(n=114)$ \\
\hline & $\begin{array}{l}\text { Standardised estimate } \\
\text { of relative risk }(95 \% \mathrm{CI})\end{array}$ & $\begin{array}{l}\text { Standardised estimate } \\
\text { of relative risk (95\% CI) }\end{array}$ \\
\hline \multicolumn{3}{|c|}{ a) Continuous variables } \\
\hline $\begin{array}{l}\text { Systolic } \\
\text { BP }\end{array}$ & $1.2(0.8-1.7)$ & $1.0(0.6-1.7)$ \\
\hline $\begin{array}{l}\text { Diastolic } \\
\text { BP }\end{array}$ & $1.2(0.8-1.7)$ & $0.8(0.5-1.3)$ \\
\hline $\begin{array}{l}\text { Serum } \\
\text { cholesterol }\end{array}$ & $1.0(0.7-1.5)$ & $1.5^{\mathrm{a}}(1.02-2.3)$ \\
\hline $\begin{array}{l}\text { Plasma } \\
\text { creatinine }\end{array}$ & $0.5^{\mathrm{b}}(0.3-0.8)$ & $1.6^{\mathrm{a}}(1.06-1.9)$ \\
\hline $\begin{array}{l}\text { Body mass } \\
\text { index }\end{array}$ & $1.3(0.9-1.7)$ & $1.1(0.8-1.6)$ \\
\hline \multirow{2}{*}{$\begin{array}{l}\text { Diabetes } \\
\text { duration }\end{array}$} & $1.1(0.7-1.6)$ & $1.2(0.9-1.7)$ \\
\hline & $\begin{array}{l}\text { Estimate of relative risk } \\
(95 \% \mathrm{CI})\end{array}$ & $\begin{array}{l}\text { Estimate of relative risk } \\
(95 \% \mathrm{CI})\end{array}$ \\
\hline \multicolumn{3}{|c|}{ b) Categorical variables } \\
\hline $\begin{array}{l}\text { Proteinuria } \\
\text { (yes/no) }\end{array}$ & $2.5^{\mathrm{b}}(1.2-5.2)$ & $5.0^{\mathrm{b}}(1.9-12.7)$ \\
\hline $\begin{array}{l}\text { ECG } \\
\text { (abnormal/ } \\
\text { normal) }\end{array}$ & $1.9(0.8-4.1)$ & $0.8(0.3-2.4)$ \\
\hline $\begin{array}{l}\text { Hypertension } \\
\text { (present/ } \\
\text { absent) }\end{array}$ & $2.0(1.0-4.1)$ & $1.5(0.6-3.9)$ \\
\hline $\begin{array}{l}\text { Smoking } \\
\text { (current/ } \\
\text { never) }\end{array}$ & $1.7(1.0-2.9)$ & $1.3(0.7-2.1)$ \\
\hline
\end{tabular}

tedly to have a significant negative correlation with mortality in men with Type 2 diabetes (SERR $=0.5, p<0.01$ ); among women with Type 2 diabetes the SERR is 1.6 $(p<0.05)$ and in patients with Type 1 diabetes of either sex the association is positive but non-significant. Serum cholesterol was significantly associated with all cause mortality among women with Type 2 diabetes (SERR $=1.5, p<0.05)$.

It is of some interest that of the other putative risk factors diastolic blood pressure, body mass index, duration of diabetes and smoking were not significantly associated with all-cause mortality among any of the four groups although the relative risks for some of the associations are of a magnitude which might be regarded as suggestive.

The significant results of age-adjusted stepwise multiple Cox regression for all-cause mortality are given in Table 5. Hypertension is significantly associated with all-cause mortality in men and in women with Type 1 diabetes with a relative risk of 4.3 in men $(p=0.05)$ and 7.2 in women $(p=0.001)$. In men with Type 2 diabetes the negative association between serum creatinine and allcause mortality seen in univariate analysis is also seen in the multivariate analysis ( $\mathrm{SERR}=0.4, p=0.003$ ). For women with Type 2 diabetes serum cholesterol 
Table 5. Variables statistically significantly associated with all-cause mortality in stepwise multiple Cox regression analysis (adjusted for age)

Patients with Type 1 (insulin-dependent) diabetes

Standard estimate/estimate of relative risk (95\% CI)
a) Males
4.3
Hypertension
$(p=0.05)$
b) Fermales
7.2
$(1.1-16.6)$
Hypertension
$(p=0.001)$
$(2.5-26.6)$

Patients with Type 2 (non-insulin-dependent) diabetes

\begin{tabular}{lll} 
a) Males & 0.4 & $(0.2-0.8)$ \\
Plasma creatinine & $(p=0.003)$ \\
b) Females & 2.1 & \\
Serum cholesterol & $(p=0.005)$ & $(1.3-3.3)$ \\
Proteinuria & 6.4 \\
& $(p=0.032)$ \\
\hline
\end{tabular}

$(\mathrm{SERR}=2.1, p=0.005)$ and proteinuria $(\mathrm{ERR}=6.4$, $p=0.032)$ are significant in the multivariate analysis.

Figure 1 shows age-adjusted death rates per 1000 person years for all-cause mortality amongst both types of diabetes categorised by the presence or absence of a) hypertension and $b$ ) proteinuria at baseline. The rates of death are four-fold higher for those patients with Type 1 diabetes who had hypertension at baseline and two-fold higher for hypertensive patients with Type 2 diabetes. Similarly for proteinuria age-adjusted death rates are three-fold greater in patients with Type 1 diabetes for those with proteinuria at baseline than without and fourfold in patients with Type 2 diabetes.

\section{Risk factors for cardiovascular and non-cardiovascular mortality}

When cardiovascular and non-cardiovascular deaths are separated by gender and diabetes type small numbers make group comparison difficult to interpret. As there ap-
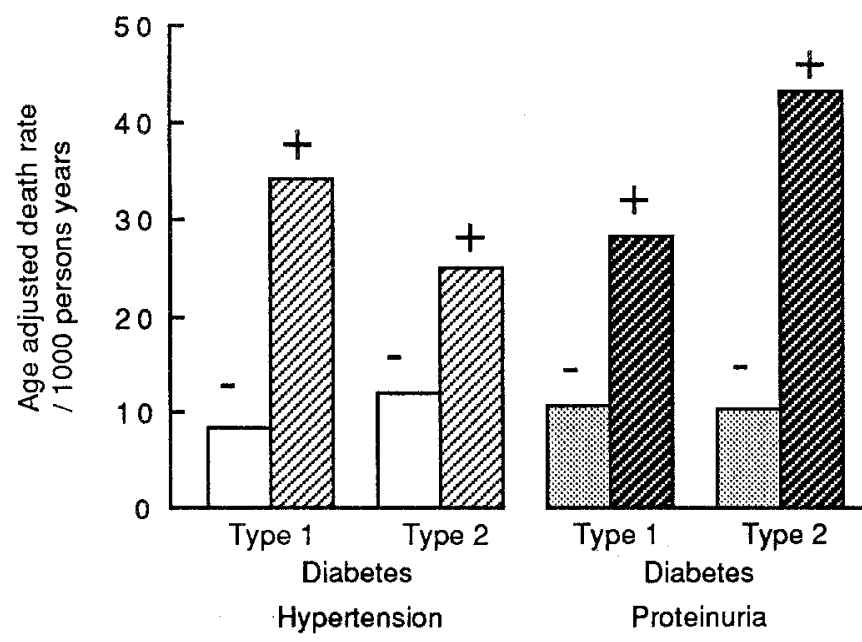

Fig. 1. Age adjusted death rates in patients with $(+)$, and without $(-)$, hypertension (left panel) and proteinuria (right panel) at baseline peared to be no major differences between genders in causes of death the results in this section are presented by diabetes type alone.

The results of univariate Cox regression analysis after adjusting for age and sex are shown for cardiovascular mortality in Table 6 and non-cardiovascular mortality in Table 7.

Amongst patients with Type 1 diabetes cardiovascular mortality was significantly associated with both systolic blood pressure (SERR $=1.9, p<0.01)$ and hypertension (ERR 4.5, $p<0.001$ ). Diabetes duration also has a significant positive link with cardiovascular mortality in patients with Type 1 diabetes (SERR 1.6, $p<0.05$ ). For patients with Type 2 diabetes the following variables were significantly linked with cardiovascular mortality; proteinuria $(\mathrm{ERR}=3.0, p<0.01)$, smoking $(\mathrm{ERR}=2.5, p<0.05)$ and BMI (SERR $=1.5, p<0.05)$; cholesterol with an SERR of 1.4 just fails to reach statistical significance $(p<0.1)$. ECG abnormality at baseline has an appreciable ERR (Type 1 diabetes $=1.9$, Type 2 diabetes $=1.8$ ) for both diabetes types but these are non-significant $(p<0.3$ and $p<0.2)$. Similarly the ERR for proteinuria in patients with Type 1 diabetes (2.4) for cardiovascular mortality is non-signifi-

Table 6. Univariate Cox regression analysis of association between risk factors and cardiovascular mortality: both sexes (adjusted for age and sex)

\begin{tabular}{|c|c|c|}
\hline & $\begin{array}{l}\text { Patients with Type } 1 \\
\text { (insulin-dependent) } \\
\text { diabetes }(n=240)\end{array}$ & $\begin{array}{l}\text { Patients with Type } 2 \\
\text { (non-insulin-dependent) } \\
\text { diabetes }(n=246)\end{array}$ \\
\hline & $\begin{array}{l}\text { Standardised estimate } \\
\text { of relative risk ( } 95 \% \mathrm{CI})\end{array}$ & $\begin{array}{l}\text { Standardised estimate } \\
\text { of relative risk }(95 \% \mathrm{CI})\end{array}$ \\
\hline \multicolumn{3}{|c|}{ a) Continuous variables } \\
\hline $\begin{array}{l}\text { Systolic } \\
\text { BP }\end{array}$ & $1.9^{\mathrm{b}}(1.2-2.8)$ & $1.3(0.9-1.8)$ \\
\hline $\begin{array}{l}\text { Diastolic } \\
\text { BP }\end{array}$ & $1.2(0.8-1.3)$ & $1.1(0.8-1.6)$ \\
\hline $\begin{array}{l}\text { Plasma } \\
\text { cholesterol }\end{array}$ & $1.1(0.7-1.7)$ & $1.4(0.98-1.9)$ \\
\hline $\begin{array}{l}\text { Plasma } \\
\text { creatinine }\end{array}$ & $1.1(0.6-1.9)$ & $0.8(0.2-7.1)$ \\
\hline $\begin{array}{l}\text { Body mass } \\
\text { index }\end{array}$ & $0.7(0.4-1.1)$ & $1.5^{2}(1.1-3.0)$ \\
\hline \multirow{2}{*}{$\begin{array}{l}\text { Diabetes } \\
\text { duration }\end{array}$} & $1.6^{\mathrm{a}}(1.1-2.5)$ & $0.9(0.7-1.3)$ \\
\hline & $\begin{array}{l}\text { Estimate of relative } \\
\text { risk }(95 \% \mathrm{CI})\end{array}$ & $\begin{array}{l}\text { Estimate of relative } \\
\text { risk }(95 \% \mathrm{CI})\end{array}$ \\
\hline \multicolumn{3}{|c|}{ b) Categorical variables } \\
\hline $\begin{array}{l}\text { Proteinuria } \\
\text { (yes/no) }\end{array}$ & $2.4(0.9-6.0)$ & $3.0^{\mathrm{b}}(1.4-6.1)$ \\
\hline $\begin{array}{l}\text { ECG } \\
\text { (abnormal/ } \\
\text { normal) }\end{array}$ & $1.9(0.9-5.9)$ & $1.8(0.8-4.0)$ \\
\hline $\begin{array}{l}\text { Hypertension } \\
\text { (present/ } \\
\text { absent) }\end{array}$ & $4.5^{\mathrm{c}}(1.8-11.1)$ & $1.9(0.9-3.9)$ \\
\hline $\begin{array}{l}\text { Smoking } \\
\text { (current/never) }\end{array}$ & $1.0(0.3-2.7)$ & $2.5^{\circledR}(1.1-6.0)$ \\
\hline
\end{tabular}


Table 7. Univariate Cox regression analysis of association between risk factors and non-cardiovascular mortality: both sexes (adjusted for age and sex)

\begin{tabular}{|c|c|c|}
\hline & $\begin{array}{l}\text { Patients with Type } 1 \\
\text { (insulin-dependent) } \\
\text { diabetes }(n=240)\end{array}$ & $\begin{array}{l}\text { Patients with Type } 2 \\
\text { (non-insulin-dependent) } \\
\text { diabetes }(n=246)\end{array}$ \\
\hline & $\begin{array}{l}\text { Standardised estimate } \\
\text { of relative risk }(95 \% \mathrm{CI})\end{array}$ & $\begin{array}{l}\text { Standardised estimate } \\
\text { of relative risk }(95 \% \mathrm{CI})\end{array}$ \\
\hline \multicolumn{3}{|c|}{ a) Continuous variables } \\
\hline $\begin{array}{l}\text { Systolic } \\
\text { BP }\end{array}$ & $1.1(0.7-1.7)$ & $1.0(0.6-1.7)$ \\
\hline $\begin{array}{l}\text { Diastolic } \\
\mathrm{BP}\end{array}$ & $1.2(0.8-1.8)$ & $0.9(0.5-1.6)$ \\
\hline $\begin{array}{l}\text { Plasma } \\
\text { cholesterol }\end{array}$ & $0.8(0.5-1.4)$ & $1.1(0.7-1.8)$ \\
\hline $\begin{array}{l}\text { Plasma } \\
\text { creatinine }\end{array}$ & $1.6^{\mathrm{a}}(1.01-2.5)$ & $0.7(0.4-1.5)$ \\
\hline $\begin{array}{l}\text { Body mass } \\
\text { index }\end{array}$ & $1.1(0.7-1.6)$ & $0.7(0.4-1.3)$ \\
\hline \multirow{2}{*}{$\begin{array}{l}\text { Diabetes } \\
\text { duration }\end{array}$} & $0.8(0.5-1.2)$ & $1.8^{\mathrm{b}}(1.2-2.6)$ \\
\hline & $\begin{array}{l}\text { Estimate of relative } \\
\text { risk }(95 \% \mathrm{CI})\end{array}$ & $\begin{array}{l}\text { Estimate of relative } \\
\text { risk }(95 \% \mathrm{CI})\end{array}$ \\
\hline \multicolumn{3}{|c|}{ b) Categorical variables } \\
\hline $\begin{array}{l}\text { Proteinuria } \\
\text { (yes/no) }\end{array}$ & $3.4^{c}(1.4-8.3)$ & $3.3^{\mathrm{b}}(1.2-9.2)$ \\
\hline $\begin{array}{l}\text { ECG } \\
\text { (abnormal/ } \\
\text { normal) }\end{array}$ & $1.3(0.4-4.5)$ & $0.7(0.1-3.1)$ \\
\hline $\begin{array}{l}\text { Hypertension } \\
\text { (present/absent) }\end{array}$ & $3.0^{\mathrm{a}}(1.2-7.2)$ & $2.0(0.7-5.7)$ \\
\hline $\begin{array}{l}\text { Smoking } \\
\text { (current/never) }\end{array}$ & $1.7(0.5-5.7)$ & $2.5(0.5-12.9)$ \\
\hline
\end{tabular}

cant $(p<0.2)$. Diastolic blood pressure has a weaker relationship than systolic blood pressure with cardiovascular mortality for both diabetes types (SERR systolic blood pressure vs diastolic blood pressure; Type 1 diabetes $1.9 \mathrm{vs}$ 1.2 , Type 2 diabetes 1.3 vs 1.1), in no case achieving statistical significance.

Non-cardiovascular mortality is strongly associated with proteinuria in patients with Type 1 diabetes and in those with Type 2 diabetes $(\mathrm{ERR}=3.4(p<0.001)$ and 3.3 $(p<0.01)$ respectively) and in patients with Type 2 diabetes with diabetes duration (SERR $=1.8, p<0.1$ ). Hypertension has a relative risk of 3.0 in patients with Type 1 diabetes $(p<0.01)$ but the association is weaker among patients with Type 2 diabetes. Plasma creatinine has an SERR of 1.6 $(p<0.05)$ for non-cardiovascular mortality among patients with Type 1 diabetes.

The relationships achieving statistically significant results of age and sex-adjusted stepwise multiple Cox regression for cardiovascular and non-cardiovascular mortality are given in Table 8 . Cardiovascular mortality in patients with Type 1 diabetes is strongly associated with hypertension with an ERR of $4.6(p<0.001)$ and with diabetes duration (SERR $=1.6, p<0.05$ ). For patients with Type 2 diabetes smoking $(\mathrm{ERR}=1.8, p<0.05)$ and
Table 8. Variables statistically significantly associated with cardiovascular and non-cardiovascular mortality in stepwise multiple Cox regression analysis (adjusted for age and sex)

Cardiovascular mortality

Standardised Estimate/Estimate of Relative Risk (95\% CI)

a) Patients with Type 1 (insulin-dependent) diabetes

Hypertension $\quad 4.6^{\mathrm{c}}(1.8-11.8)$

Diabetes duration $\quad 1.6^{\mathrm{a}}(1.01-2.5)$

b) Patients with Type 2 (non-insulin-dependent) diabetes

Smoking $\quad 1.8^{\mathrm{a}}(1.1-2.9)$

Proteinuria $\quad 3.1^{\mathrm{a}}(1.4-6.2)$

Non-cardiovascular mortality

a) Patients with Type 1 (insulin-dependent) diabetes

Hypertension $\quad 3.0^{\mathrm{a}}(1.1-7.9)$

b) Patients with Type 2 (non-insulin-dependent) diabetes

Diabetes duration $\quad 2.7^{\mathrm{b}}(1.4-5.1)$

${ }^{\mathrm{a}} p<0.05 ;{ }^{\mathrm{b}} p<0.01 ;{ }^{\mathrm{c}} p<0.001$

proteinuria $(\mathrm{ERR}=3.1, p<0.05)$ are significant in the multivariate analysis.

In patients with Type 1 diabetes hypertension has a significant association with non-cardiovascular mortality $(\mathrm{ERR}=3.0, p<0.05)$. In patients with Type 2 diabetes, diabetes duration reaches significance $(\mathrm{SERR}=2.7$, $p<0.01$ ). Proteinuria, significant in univariate analysis among patients with both types of diabetes, is not selected by the stepwise multiple regression process in either group.

\section{Interaction between hypertension and proteinuria}

In view of the prominence of hypertension and proteinuria in the results and of their biological relationships the multiple regression analyses were repeated including a term representing the interaction between them. The effects of hypertension and proteinuria remained significant despite the presence of the interactive term and in no case was the interactive term significantly associated with mortality. This indicates that the effects of hypertension and proteinuria on mortality are independent of each other.

\section{Discussion}

There are relatively few prospective studies of defined diabetic populations over substantial time periods and employing standardised indices of risk on the initial assessment. With the exception of the relatively small and very selective populations of diabetic subjects documented and followed up in the Bedford [5] and Whitehall [6] surveys there are few in the United Kingdom.

Persistent proteinuria [7] and diabetic nephropathy [8] are associated with a consistently increased incidence of coronary heart disease among patients with Type 1 diabetes. A recent report highlighted the relationship of persistent proteinuria and deaths from macrovascular disease among Danish patients with Type 1 diabetes [9]. In our cohort of the WHO Study proteinuria was significant- 
ly associated in univariate analysis with all-cause mortality in three of the four sex/diabetes-type groups, with cardiovascular mortality among patients with Type 2 diabetes and with non-cardiovascular mortality among patients with either diabetes type. In multivariate analysis proteinuria significantly predicts both all-cause mortality and cardiovascular mortality in patients with Type 2 diabetes. The association with cardiovascular mortality appears less strong among our patients than in other reports but our definition of proteinuria was based on a single measurement unlike the multiple positive tests obtained in the Danish studies and may therefore represent a lesser degree of renal impairment. The finding that the detection of even a low level of proteinuria on a single occasion significantly predicts mortality gives strong support to the importance of its association with mortality in both diabetes types. The finding that plasma creatinine is inversely correlated with all-cause mortality in men with Type 2 diabetes in both uni- and multi-variate analysis is unexpected and contrasts with the significant positve correlation for women with Type 2 diabetes and the positive but non-significant associations in patients with Type 1 diabetes. Serum creatinine is significantly correlated with non-cardiovascular mortality in patients with Type 1 diabetes. The explanation for the inverse correlation among men with Type 2 diabetes is not clear and may lack biological relevance; further information on this point may be available when the analysis of the morbidity follow-up is complete.

Hypertension has been reported to have both a greater [10] and a similar [11, 12] significance in predicting mortality in diabetic subjects compared with non-diabetic subjects. In our patients systolic blood pressure was more consistently and closely associated with mortality than diastolic blood pressure. The effect of hypertension appeared stronger in patients with Type 1 diabetes than with Type 2 diabetes perhaps because of its close association with diabetic kidney disease in the former. Hypertension was significantly associated with all-cause mortality in both sexes and with both cardiovascular and non-cardiovascular mortality in patients with Type 1 diabetes in the multivariate analysis.

A significant association with total serum cholesterol is seen with all-cause mortality in women with Type 2 diabetes. The absence or inconsistency of significant associations between mortality and some conventional risk factors such as serum cholesterol and smoking is of interest. The failure to demonstrate a relationship may simply be due to relatively small numbers, although the effect of arterial blood pressure and hypertension was clear despite that. Blood pressure can account for only a part of the mortality seen in the group and this suggests that there may be other, relatively powerful and as yet undefined risk factors in some way associated with diabetes to account for the larger part of the excess risk. From analysis of a ten year follow-up of male civil servants with diabetes Fuller et al. [13] showed that allowing for conventional risk factors explained only about one third of the excess risk of death from coronary heart disease. However, at each level of risk factor there were about twice as many deaths in glucose intolerant than in control subjects. The Framingham Study showed a relative risk for cardiovascular disease death of 1.7 for men and 3.3 for women after adjusting for other risk factors in the 20 year follow-up analysis [14]. Clustering of risk factors has been noted to be more common in diabetic subjects than non-diabetic subjects [15] and it is possible that synergism between risk factors may play a part in the excess mortality in addition to the possible action of 'diabetic' risk factors.

The nature of diabetes related additional factors remains uncertain. Of the many candidate mechanisms that have been put forward we hope to have information on haemostatic factors and lipid fractions which were measured at baseline in a proportion of this cohort.

The relationship of mortality with proteinuria in diabetes suggests that the link might underlie the nature of the excess cardiovascular mortality in diabetes. Proteinuria and diabetic nephropathy are linked with elevated arterial pressure [16], atherogenic patterns of plasma lipids [17] and abnormalities of haemostatic factors [18] which are likely themselves to contribute to the enhanced risk of coronary heart disease; these changes have recently been shown to be present even at the stage of microalbuminuria [19] leading to the conclusion that part of the link between renal involvement and atherosclerosis in diabetes may be due to a prolonged exposure to an atherogenic risk factor pattern which may precede clinical proteinuria by a considerable period. There is, however, some evidence that even after allowing for the confounding effect of such linked factors there still remains an unexpected excess of coronary heart disease. There is growing evidence that the liability to proteinuria may be a marker for a generalised increase in vascular permeability and that this factor may make a considerable contribution to the enhanced susceptibility of the diabetic subject to arterial disease [20].

Acknowledgements. The project was supported by a Medical Research Council Project Grant. We would like to thank the Staff of the Diabetic Departments of King's College Hospital and St Thomas' Hospital for their co-operation.

\section{References}

1. The World Health Organisation Multinational Study of Vascular Disease in Diabetics (1985) Prevalence of small vessel and large vessel disease in diabetic patients from 14 centres. Diabetologia 28 [Suppl]: 615-640

2. Morrish NJ, Stevens LK, Head J, Fuller JH, Jarrett RJ, Keen H (1990) A prospective study of mortality among middle-aged diabetic patients (The London cohort of the WHO Multinational Study of Vascular Disease in Diabetics) I: causes and death rates. Diabetologia 33: 538-541

3. Rennie IDB, Keen H, Cowhig J, Field M, Harvey M, Quartey E (1967) Evaluation of clinical methods for detecting proteinuria. Lancet II: 489-492

4. Dixon WJ (Ed) (1985) BMDP Statistical Software. University of California Press, Berkeley, pp 576-594

5. Jarrett RJ, McCartney P, Keen H (1982) The Bedford survey: ten year mortality rates in newly diagnosed diabetics, borderline diabetics and normoglycaemic controls and risk indices for coronary heart disease in borderline diabetics. Diabetologia 22: $79-84$ 
6. Fuller JH, Shipley MJ, Rose G, Jarrett RJ, Keen H (1983) Mortality from coronary heart disease and stroke in relation to degree of glycaemia: the Whitehall study. Br Med J 287: 867-870

7. Krolewski AS, Kosinski EJ, Warram JH, Leland S, Busick EJ, Asmal AC, Rand LI, Christlieb AR, Bradley RF, Kahn CR (1987) Magnitude and determinants of coronary artery disease in juvenile onset, insulin-dependent diabetes mellitus. Am J Cardiol 59: 750-755

8. Jensen T, Borch-Johnson K, Kofoed-Enevoldson A, Deckert T (1987) Coronary heart disease in young Type 1 (insulin-dependent) diabetic patients with and without diabetic nephropathy: incidence and risk factors. Diabetologia 30: 144-148

9. Borch-Johnsen K, Kreiner S (1987) Proteinuria: value as a predictor of cardiovascular mortality in diabetes mellitus. Br Med J 294: $1651-1654$

10. Goodkin G (1975) Mortality factors in diabetics. J Occup Med 17: 716-721

11. Kannel WB, McGee DL (1979) Diabetes and cardiovascular risk factors: the Framingham study. Circulation 59: 8-13

12. Pell S, D'Alonzo A (1970) Factors associated with long-term systolic blood pressure survival in diabetics. JAMA 214: 1833-1840

13. Fuller JH, Shipley MJ, Rose G, Jarrett RJ, Keen H (1983): Mortality from coronary heart disease and stroke in relation to degree of glycaemia: the Whitehall study. Br Med J 287: 867-870

14. Kannel WB, McGee DL (1979) Diabetes and cardiovascular disease: the Framingham study. JAMA 241: 2035-2038

15. Wingard DL, Barrett-Connor E, Criqui MH, Suarez L (1983) Clustering of heart disease risk factors in diabetic compared to nondiabetic adults. Am J Epidemiol 117: 19-26
16. Winocour PH, Durrington PN, Ishola M, Anderson DC, Cohen $H$ (1987) Influence of proteinuria on vascular disease, blood pressure and lipoproteins in insulin dependent diabetes mellitus. Br Med J 294: 1648-1651

17. Jensen T, Stender S, Deckert T (1988) Abnormalities in plasma concentrations of lipoproteins and fibrinogen in Type 1 (insulindependent) diabetes with increased urinary albumen excretion. Diabetologia 31: 142-145

18. Fuller JH, Keen H, Jarrett RJ, Omer T, Meade TW, Chakrabarti R, North WRS, Stirling Y (1979) Haemostatic variables associated with diabetes and its complications. Br Med J 2:964-966

19. Jones SL, Close CF, Mattock MB, Jarrett RJ, Keen H, Viberti GC (1989) Plasma lipid and coagulation factor concentrations in insulin dependent diabetics with microalbuminuria. Br Med J 298: $487-490$

20. Deckert T, Feldt-Rasmussen B, Borch-Johnson K, Jensen T, Kofoed-Enevoldsen A (1989) Albuminuria relects widespread vascular damage, the Steno hypothesis. Diabetologia 32:219-226

Received: 12 December 1989

and in revised form: 22 March 1990

Dr. N.J. Morrish

Unit for Metabolic Medicine

4th floor Hunt's House

Guy's Hospital

London SEI 9RT

UK 